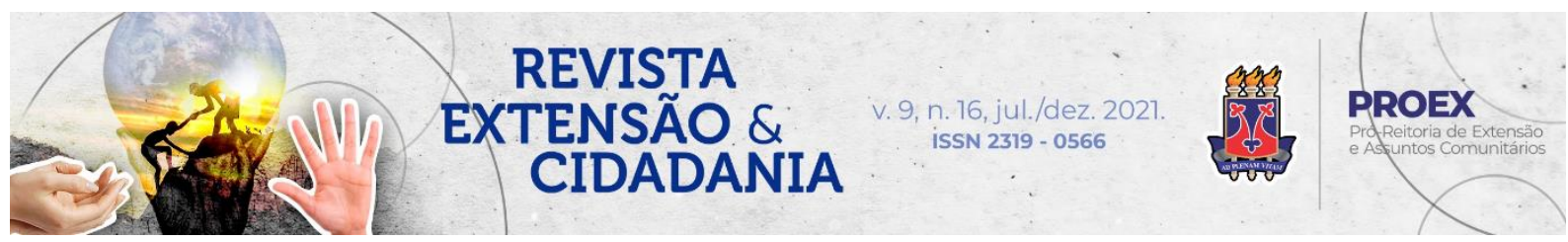

DOI: $10.22481 /$ recuesb.v9i16.8661

\title{
ANÁLISE DA RECEPÇÃO EM TEIXEIRA DE FREITAS DE MENSAGENS ESCRITAS POR PESSOAS PRESAS
}

\author{
ANALYSIS OF MESSAGES WRITTEN BY PRISON PEOPLE IN TEIXEIRA DE \\ FREITAS
}

\author{
ANÁLISIS DE MENSAJES ESCRITOS POR PERSONAS PRISIONERAS EM \\ TEIXEIRA DE FREITAS
}

\begin{abstract}
Alcides Gomes Oliveira ${ }^{1}$
Resumo: O presente artigo analisa as reações às mensagens escritas no Conjunto Penal de Teixeira de Freitas-BA, a fim de investigar a recepção da população teixeirense ao sujeito encarcerado. Tais mensagens foram produzidas no interior do projeto de extensão Narrativas dos Invisíveis (UFSB), que buscou fazer com que as vozes de pessoas em situação de privação da liberdade extrapolassem os muros do sistema prisional. A pesquisa apresentada neste artigo surge como uma aposta na promoção do contato entre a população "livre" e o sistema prisional, além de contribuir para que essas vozes ecoem cada vez mais longe. Realizou-se coleta de dados mediante a aplicação de um questionário com perguntas abertas e fechadas como também uma revisão bibliográfica concernente ao tema. Os dados obtidos evidenciam que por mais que haja estudos, matérias e informações disponíveis a quase toda a sociedade brasileira, ainda imperam no imaginário social estigmas sobre o indivíduo privado de liberdade ou egresso do sistema penal, em contrapartida, existe uma convicção e uma receptividade por parte da sociedade.

Palavras chave: Narrativas. Apenado. Ressocialização. Sistema carcerário. Sociedade.

Abstract: This article analyzes reactions to messages written in the Penal Complex of Teixeira de Freitas-BA, in order to investigate the reception of the teixeira population to the incarcerated subject. Such messages were produced through the extension project Narrativas do Invisiveis (UFSB), which sought to make the voices of people in situations of deprivation of liberty go beyond the walls of the prison system. The research presented in this article emerges as a bet on promoting contact between the "free" population and the prison system, in addition to contributing to these voices echoing ever further. Data collection was carried out through the application of a questionnaire with open and closed questions as well as a literature review concerning the topic. The captured data show that even though there are studies, materials and

\footnotetext{
${ }^{1}$ Graduando do Bacharelado Interdisciplinar em Humanidades, pela Universidade Federal do Sul da Bahia (UFSB), Teixeira de Freitas, Bahia, Brasil. Orcid: https://orcid.org/0000-0003-3267-415X E-mail: alcidesoliveira140@gmail.com
} 
information available to almost the entire Brazilian society, stigmas about the individual deprived of liberty or ex-prisoners still prevail in the social imagination, on the other hand, there is a conviction and receptivity for part of society.

Keywords: Narratives. Jailed. Resocialization. Prison system. Society.

Resumen: Este artículo analiza las reacciones a los mensajes escritos en el Complejo Penal de Teixeira de Freitas-BA, con el fin de investigar la recepción de la población teixeira al sujeto preso. Dichos mensajes fueron producidos dentro del proyecto de extensión Narrativas dos Invisiveis (UFSB), que buscaba hacer que las voces de las personas en situaciones de privación de libertad traspasaran los muros del sistema penitenciario. La investigación que se presenta en este artículo surge como una apuesta por promover el contacto entre la población "libre" y el sistema penitenciario, además de contribuir a que estas voces resuenen cada vez más lejos. La recolección de datos se llevó a cabo mediante la aplicación de un cuestionario con preguntas abiertas y cerradas, así como una revisión de la literatura sobre el tema. Los datos obtenidos muestran que, a pesar de que existen estudios, materiales e información a disposición de casi toda la sociedad brasileña, los estigmas sobre el individuo privado de libertad o ex-presos aún prevalecen en el imaginario social de la sociedad.

Palabras clave: Narrativas. Convicto. Resocialización. Sistema penitenciario. Sociedad.

\section{Introdução}

O Brasil ocupa o terceiro lugar no ranking de maiores populações carcerárias do mundo, conforme o Levantamento Nacional de Informações Penitenciárias (INFOPEN) (BRASIL, 2020) disponível e realizado no período de janeiro a junho de 2020, o número de pessoas privadas de liberdade no Brasil é de 759.518 presos, dispondo apenas de 446.738 vagas, tendo assim um excedente de 321.780 presos, quase o dobro do número de vagas nas prisões. O primeiro lugar é ocupado pelos Estados Unidos com um total de 2,09 milhões de pessoas presas e a China ocupa o segundo lugar com população carcerária de 1,7 milhão, segundo o levantamento mundial de informações penitenciárias feito pelo World Prison Brief (WORLD PRISON BRIEF, 2018).

Dentre o conjunto de pessoas privadas de liberdade no país, 21,22\% são jovens entre 18 e 24 anos, seguido de 20,69\% na faixa etária de 25 a 29 anos, 95,09\% são homens, 50,28\% são pardos e 16,03\% são pretos (pardos e pretos somados representam 66,31\% do total). Ressaltamos que o Levantamento do Infopen (BRASIL, 2020) concernente a raça, apenas foram categorizados 599.932 indivíduos privados de liberdade de um total de 759.518 internos do sistema prisional, representando assim, 79.6\% da população carcerária.

Revista Extensão \& Cidadania, v. 9, n. 16, p. 194-211, jul./dez. 2021.

ISSN 2319-0566

DOI: $10.22481 /$ recuesb.v9i16.8661 
Trazendo esta análise para a realidade da cidade de Teixeira de Freitas, na Bahia, delimitação escolhida para a pesquisa, a cidade teixeirense por sua vez conta com uma população estimada de mais de 160 mil habitantes, 114.644 pessoas com idade ativa e apenas com 69.043 da População Economicamente Ativa (PEA), tendo assim quase metade da população ativa sem atividade laboral formal, segundo o último censo feito pelo IBGE (2010).

Atualmente, a cidade dispõe de uma unidade prisional que é o Conjunto Penal de Teixeira de Freitas (CPTF), com 316 vagas prisionais, sendo 56 na ala feminina e as outras 260 distribuídas em duas alas masculinas. O número de internos no CPTF chegou em setembro de 2020 (um dos meses de aplicação do questionário) à cifra de 587 presos(as), sendo assim, um excedente de 271 presos. Em relação à ocupação em setembro de 2020 eram 182 presos em regime fechado, 3 em regime semiaberto e 399 presos provisórios (sem sentença condenatória) (BAHIA, 2020), mesmo diante de uma pandemia que tirou a vida de milhares de pessoas por todo mundo e causou diversos colapsos na saúde, na economia, no emprego, dentre outros setores. O isolamento e o distanciamento social são algumas das medidas de combate à proliferação da Covid-19, distanciamento que não existe na prisão, apenas, quando é para segregá-los do restante da sociedade que se divide entre cidadãos do "bem" e os do "mal".

Observa-se que a maior parte do expressivo número de pessoas privadas de liberdade no Brasil é composta por jovens negros, sendo os crimes mais comuns os relacionados ao tráfico de drogas. Isso acarreta diversos problemas para os familiares, para a ordem social e para o próprio indivíduo preso, como relações sociais, profissionais e pessoais, prejudicando competências fundamentais à vida em sociedade, como a capacidade comunicacional (SILVA, 2018).

A partir do "Mensagem na Garrafa", uma atividade do projeto Narrativas dos Invisíveis ${ }^{2}$ com presas e presos do CPTF de escrita de mensagens voltadas à sociedade, surgiu este estudo, que tem por objetivo principal, analisar a receptibilidade da população teixeirense a essas mensagens. Buscamos sondar as reações, identificando vetores sociais como faixa etária,

\footnotetext{
2 Projeto de extensão vinculado à Universidade Federal do Sul da Bahia (UFSB), coordenado pelo professor Rodrigo Oliveira Fonseca e tendo como bolsista a estudante do curso Bacharelado Interdisciplinar em Humanidades Maria Santos Silva da Cruz. Esse projeto desenvolvido em 2019 dentro do Conjunto Penal de Teixeira de Freitas (CPTF) tem por objetivo estimular presos(as) condenados e provisórios a exercitar a memória, da reflexão crítica e das linguagens e à escrita e reescrita de si, a fim de que seja resgatado o significado de ressocialização para eles mesmos e para sociedade em geral.
}

Revista Extensão \& Cidadania, v. 9, n. 16, p. 194-211, jul./dez. 2021. 
escolaridade e ocupação profissional dos respondentes, assim como verificar as imagens feitas sobre as pessoas presas e sobre as suas possibilidades de reintegração social.

\section{O Sistema Penal e as mensagens que dele nos chegam}

$\mathrm{O}$ atual cenário do sistema prisional brasileiro demonstra diversos problemas e dificuldades que impossibilitam o cumprimento da pena e a ressocialização dos apenados. Problemas estes que perseguem a população carcerária há anos, necessitando de mudanças que dificilmente podem ser feitas ou solucionadas a curto prazo. A Lei de Execução Penal (LEP) Lei $n^{\circ}$ 7.210, de 11 de julho de 1984 (BRASIL, 1984), apresenta em seu Art. $1^{\circ}$ que "A execução penal tem por objetivo efetivar as disposições de sentença ou decisão criminal e proporcionar condições para a harmônica integração social do condenado e do internado.” (BRASIL, 1984).

Por um lado, a lei assegura o cumprimento da sentença e por outro tenta garantir as condições humanas para a reintegração social dos presos e internos, no entanto, o que se tem no Brasil é um descaso das prisões tanto pelo Estado quanto pela sociedade. A superlotação, falta de profissionais especializados e qualificados, estruturas precárias e péssimas condições alimentares, por vezes contribuem para uma segregação social do apenado, inviabilizando o processo de sua reinserção à sociedade. No Art. $4^{\circ}$ da LEP afirma-se que "O Estado deverá recorrer à cooperação da comunidade nas atividades de execução da pena e da medida de segurança.” (BRASIL, 1984)

Quando analisada a situação dos presídios, pouco se faz presente a comunidade, e, dessa pouca presença da sociedade destacam-se as igrejas que têm em seu papel levar a religiosidade para esses detentos e os poucos acadêmicos que buscam pesquisar esse "universo" da criminalidade. A participação da sociedade na ressocialização do apenado além de contribuir para a desconstrução de estereótipos, colabora para inclusão do egresso, na medida em que, fazer parte ou ser acolhido por um grupo social contribui para que esse indivíduo se afaste de atividades criminosas, que têm por consequência a submersão no mundo do crime. Segundo Ribeiro, Brito e Oliveira:

Importante destacar novas concepções do Direito Penal que idealizam a execução penal como obrigação do Estado e da sociedade, estendendo a responsabilidade pela regeneração da comunidade carcerária para os demais cidadãos. Nesse sentir [sentido], todos os membros da sociedade são chamados a interagir no processo de reciclagem dos entes desviados pelo

Revista Extensão \& Cidadania, v. 9, n. 16, p. 194-211, jul./dez. 2021. 
crime, geralmente abandonados e esquecidos nos presídios, como forma de repúdio da comunidade. (RIBEIRO; BRITO; OLIVEIRA, 2018, p. 205)

A sociedade desempenha um importante papel não só na ressocialização do apenado, mas também na construção desse indivíduo delinquente. Considerando que a maioria dos expresidiários(as) são pessoas que não tiveram seus direitos assegurados, dentre eles: a educação como fator preponderante não formação de profissionais para o mercado de trabalho, a saúde que pouco se faz presente nas camadas mais pobres, a alimentação adequada e a segurança pública que quando presente, desempenha um papel violento na repressão da comunidade. E quando dentro do sistema prisional, não há qualquer condição mínima que garanta o cumprimento da sentença e a ressocialização do indivíduo na sociedade.

Nesse sentido, antes de tudo, é preciso reparar as desigualdades sociais, o que Baratta (1990) aponta como um processo primário no qual esses indivíduos já são segregados antes mesmo de serem aprisionados e, posteriormente, processo secundário, quando o indivíduo passa pelo processo de readaptação ao convívio social e é marcado por estereótipos sociais e a sociedade que novamente os segrega.

No que se trata dos direitos básicos assegurados aos egressos, a LEP (BRASIL, 1984) reitera que os indivíduos presos devem receber ajuda assistencial para que assim estejam aptos para o retorno à sociedade. Dessa assistência cabe ao Estado, segundo Art. 11, a assistência material; de saúde; jurídica; educacional; social e religiosa. Sendo que no processo de cumprimento da pena o delinquente "perde sua identidade" e as referências do mundo exterior, passa a conviver em um outro lugar onde o medo e a lei do mais forte prevalece. $\mathrm{O}$ apenado sai de cena como sujeito ativo na sociedade e torna-se sujeito passivo, submisso a um sistema (LEANDRO; CÓRDOVA; CASTRO; KERN, 2018). As constantes humilhações, agressões tanto por policiais quanto por outros indivíduos delinquentes, modificam a identidade do sujeito. Sendo assim, o sistema prisional não cumpre seu dever que é assegurar o cumprimento da pena e ressocialização do indivíduo para o convívio em sociedade. Tornando assim, as penitenciárias, verdadeiras escolas do crime (RIBEIRO; BRITO; OLIVEIRA, 2018; ASSIS, 2007).

Ainda em se tratando dos direitos assegurados aos internos nas prisões, a LEP (BRASIL, 1084), em seu Art .41, inciso XV, assegura o "contato com o mundo exterior por meio de correspondência escrita, da leitura e de outros meios de informação que não comprometam a

Revista Extensão \& Cidadania, v. 9, n. 16, p. 194-211, jul./dez. 2021. 
moral e os bons costumes". Desse modo, extingue-se o direito às mensagens escritas ou qualquer outro meio de comunicação reconhecido ao apenado, quando submetidos a moral e os bons costumes da sociedade, sendo passível da sua violação ou suspensão da autoridade pública. Embora na sociedade vigente essas mensagens manuscritas foram perdendo seu "valor" e sendo o papel, a caneta e o envelope cada vez mais substituídos por meios de comunicação eletrônicos que, por vez, transmitem a mensagem do emissor de forma instantânea a diversas pessoas e lugares ao mesmo tempo. Assim sendo, um meio de comunicação pouco usual no dia a dia da população brasileira "livre", ela ainda se faz muito presente no sistema prisional brasileiro. No entanto, há uma exposição do interlocutor e do receptor dessas mensagens, que é feita através de um ato de censura que objetiva identificar nessas mensagens informações que podem a vir prejudicar e ameaçar o funcionamento da prisão e a segurança daqueles que nela estão presentes (FLAUZINA; PIRES, 2019; SILVA, 2014).

As narrativas contidas nessas mensagens recebem não só estímulo subjetivo da necessidade de comunicação, mas também de outros atores que estão presentes no cárcere, como os integrantes do projeto de extensão Narrativas dos Invisíveis, da Universidade Federal do Sul da Bahia (UFSB), que com um papel, caneta e uma escuta sensível conseguiram resgatar as memórias esquecidas desses indivíduos segregados. Este projeto tem por objetivo incentivar a escrita de si mesmo e, a partir dessa escrita, buscar juntamente com esses indivíduos presos os significados da ressocialização para si mesmo e para a sociedade.

Ao longo dos diálogos promovidos pelo grupo de extensão, foram introduzidas nas rodas de conversas temas como ressocialização, perguntas de como eles se veriam depois do cumprimento da pena e como as pessoas aqui fora receberiam as mensagens escritas por eles. A partir dessa provocação de escrever essas mensagens que, posteriormente, foram transformadas em vídeos narrados pelos estudantes integrantes do projeto e seu coordenador, esses indivíduos privados de liberdade direcionaram suas mensagens para a sociedade de indivíduos "livres", como os familiares junto aos quais buscam apoio moral e demonstração de arrependimento, as instituições nas quais buscam apoio político, jurídico e religioso, grupos de pesquisadores que trabalham com esses sujeitos em suas pesquisas e dentre outros diversos grupos sociais e à sociedade em geral. Silva, ao considerar o pensamento de Dias (2008), afirma que:

[...] ao pensar a escrita através de um gesto denominado corpografia, ou seja, uma escrita determinada por um corpo em estado afetivo e emocional que dela

Revista Extensão \& Cidadania, v. 9, n. 16, p. 194-211, jul./dez. 2021.

ISSN 2319-0566

DOI: $10.22481 /$ recuesb.v9i16.8661 
se utiliza para manter, ou construir, laços de pertencimento com sua comunidade, sua nação, seu gueto, abre possibilidades para pensar na produção dessas cartas, enquanto instrumento de pertencimento entre esse eu que está dentro e o outro que está fora e com condições para aliviar sua pena. (SILVA, 2014, p. 79)

Nessa perspectiva, por meio dessas mensagens escritas o sujeito consegue encontrar a si mesmo e ao outro, "porque o ato de escrever é a tentativa de suturar uma perda, e é movido por esse impossível que o sujeito escreve" (DIAS, 2008, p. 27). Através desse ato de escrever, podemos entender essas mensagens e nos conectar com a realidade dessas pessoas encarceradas, além de compreender a performance de poder que o Estado opera sobre essas pessoas que as desumanizam e deterioram ainda mais suas condições de partilha e integração social.

Em sua pesquisa desenvolvida por meio da Análise do Discurso ${ }^{3}$, Silva (2014) fez uma sondagem de um conjunto de cartas produzidas por pessoas presas no sistema penal do Estado do Paraná que, por meio delas, esses indivíduos tinham como objetivo usufruir desse direito assegurado a eles como um meio de manter o contato com a sociedade fora dos muros das prisões. Desse modo, esses indivíduos são levados a escreverem sobre eles mesmos, e a partir disso, a autora buscou os significados que essas cartas produzem para os presos e para os outros. Para que essas cartas ultrapassem os muros das prisões e cheguem até seus receptores finais, essas mensagens passam por três processos: autoanálise, censura e convencimento (PIRES; FREITAS, 2018).

O primeiro processo corresponde à análise de si e do outro que receberá essa carta, ainda nesse processo apresenta-se um outro sujeito a ser analisado, que é o agente penitenciário responsável por decidir sobre o envio ou não dessas cartas. Assim, a carta não é algo privado mediante a intervenção do Estado por meio dos agentes responsáveis por lerem e decidirem sobre o destino final dela (SILVA, 2014; PIRES; FREITAS, 2018).

A censura é um ato de proteger aqueles que ali estão à serviço do Estado e os internos do sistema prisional. Este ato de censura também ocorre ainda na produção dessas mensagens, quando o sujeito é levado a pensar sobre o que é permitido ou não estar contido nessas

\footnotetext{
${ }^{3}$ Análise do Discurso (AD), uma disciplina que surge na França, no final da década de 1960, e tem como o seu principal expoente e fundador Michel Pêcheux e, posteriormente, é desenvolvida no Brasil por Eni Orlandi e seguidores. Na AD procura-se estabelecer a relação entre um discurso e as condições de produção que permite que ele gera determinados efeitos de sentido em detrimento de outros (BRASIL, 2011).
}

Revista Extensão \& Cidadania, v. 9, n. 16, p. 194-211, jul./dez. 2021. 
mensagens. Também quando há uma perda da subjetivação fechada sobre si mesmo que ocorre mediante o aprisionamento de indivíduo, que é depois reterritorializado, agora com a cultura do cárcere (ONOFRE, 2014). Sendo que por meio desse ato de ler esses manuscritos buscando informações que possam vir a prejudicar o funcionamento do sistema prisional, o agente penitenciário ou indivíduo designado para esta função viola a privacidade e a intimidade que ali estava contida na mensagem.

Por fim, depois de ter superado todos esses dois processos anteriores, a mensagem é liberada e encaminhada para seus destinatários. Essa mensagem escrita tem em sua obrigação de convencer quem a ler, no sentido de trazer esse leitor para seu "universo" por meio das suas inquietudes, angústias, solidão e arrependimentos como mencionado outrora. Ou seja, essa mensagem tem por objetivo conectar pessoas por meio da comunicação escrita e por elas criarem diversos significados que cabe ao receptor dessas mensagens compreendê-los.

\section{Procedimentos metodológicos}

Para execução da presente pesquisa definiu-se a realização de uma sondagem e um mapeamento da recepção de diferentes segmentos sociais de Teixeira de Freitas a mensagens escritas por pessoas presas no Conjunto Penal de Teixeira de Freitas. Tais mensagens foram produzidas no âmbito do projeto de extensão Narrativas dos Invisíveis, coordenado por Rodrigo Oliveira Fonseca, professor da UFSB, e depois transformadas em pequenos vídeos editados pela equipe do referido projeto de extensão. Trata-se de uma pesquisa de base qualitativa e quantitativa.

A proposta inicial deste estudo era de uma pesquisa em campo com uma abordagem direta dos possíveis entrevistados em espaços públicos e privados, com a finalidade de ter uma proximidade com o público. Tal proposta não pode ser realizada, devido ao advento do vírus SARS-CoV-2, que se alastrou por todo o mundo fazendo com que o isolamento social fosse adotado como medida preventiva de combate à proliferação. Assim, optou-se pela aplicação do questionário de forma online, que ficou disponível entre os meses de julho a dezembro de 2020.

A partir da substituição da abordagem direta pela aplicação de questionário online, buscou-se evitar os riscos de uma sondagem desterritorializada ou indiferente ao território, selecionando apenas os respondentes que dissessem residir em Teixeira de Freitas. Mesmo

Revista Extensão \& Cidadania, v. 9, n. 16, p. 194-211, jul./dez. 2021. 
assim, obtivemos a participação de grupos das mais variadas faixas etárias, comerciantes locais prioritariamente que estão a mais tempo no comércio, residentes dos mais variados bairros e escolaridade, de modo que mesmo havendo maior participação de universitários, obteve-se uma amostra socialmente diversificada. Os dados foram coletados por meio da aplicação do formulário hospedado em ambiente virtual da UFSB, com perguntas idênticas para todos os entrevistados, o que possibilitou estabelecer uniformidade e a comparação entre as respostas.

Para a divulgação do instrumento de coleta de dados, foram postados links do questionário em diversos ambientes virtuais como Whatsapp, Facebook, Instagram, sendo enviados diretamente aos respondentes por meio dos seus perfis pessoais ou postados em grupos dessas redes sociais e para que tivesse uma maior alcance possível de respondentes, contamos com a ajuda do compartilhamento de diversas pessoas, dentre elas, conhecidos, amigos, colegas, etc. Ressaltamos que, durante a aplicação do questionário, ele era respondido de forma anônima, sem identificação do indivíduo respondente.

No que tange ao instrumento aplicado, o questionário foi dividido em três blocos. No primeiro bloco, buscou-se identificar o perfil social dos respondentes: faixa etária, gênero, raça, escolaridade e profissionalização. No segundo bloco, buscou-se aferir o nível de proximidade com o tema e o sistema prisional, a partir das seguintes perguntas:

- Já esteve preso?

- Conhece alguém que está ou já esteve preso?

- Na sua opinião, qual o motivo principal que leva as pessoas a cometerem crimes?

- Quem passa pelo sistema penitenciário brasileiro, mesmo após ter cumprido sua pena, muitas vezes fica marcado como ex-presidiário ou até mesmo bandido, o que torna mais difícil conseguir um emprego. Se pudesse, você contrataria um expresidiário?

Por fim, o terceiro bloco buscou testar a sensibilidade frente a mensagens escritas por presidiários(as). Nesta parte, foi inserido um link do canal no Youtube onde os respondentes pudessem escolher um dos vários vídeos do Projeto de Extensão Narrativas dos Invisíveis da UFSB com mensagens narradas de presos(as) do CPTF para assistir e logo após retornar ao questionário respondendo às seguintes perguntas:

- Qual o vídeo você assistiu?

- Você se importaria de trabalhar com essa pessoa?

Revista Extensão \& Cidadania, v. 9, n. 16, p. 194-211, jul./dez. 2021. 
- Se pudesse, você contrataria essa pessoa?

- Gostaria de deixar um recado para essa pessoa?

A análise dos dados coletados foi realizada entre dezembro e janeiro de 2020. Os dados foram tratados no Microsoft Excel que possibilitou a análise estatística descritiva juntamente com o amparo da literatura. Além disso, o processo de tratamento dos dados em planilha, também possibilitou agrupar as perguntas e respostas em primárias e secundárias para que posteriormente pudessem ser melhor analisadas.

Para o processo de análise dos dados obtidos recorreu-se à revisão bibliográfica sobre a história das compreensões teóricas da relação entre o indivíduo delinquente, a sociedade e à Análise de Conteúdo (AC), que segundo Bardin (1988) trata-se de um conjunto de técnicas ou procedimento sistemático da comunicação que tem por objetivo fazer inferência, ou seja, retirar conclusões de uma proposição precedente para outra.

\section{Resultados}

Em relação ao perfil sociodemográfico, quando analisada a variável gênero, observouse que da amostra analisada, 46,06\% dos respondentes eram do gênero masculino, 44,24\% do gênero feminino e 9,70\% dos dados coletados não apresentou tal informação, ou seja, constatou-se uma predominância do gênero masculino. Quanto à faixa etária, as faixas entre 15 a 19 e entre 20 a 24 anos apresentaram os maiores percentuais, ambos com 18,18\%. A cor parda obteve a maior parte das respostas desse quesito, 50,30\%, quase que o dobro comparado à raça preta, com $27,88 \%$ das respostas. No item escolaridade, $29,09 \%$ dos respondentes disseram ter o ensino superior incompleto. No que se refere à profissionalização, 43,03\% estavam desempregados. Os resultados podem ser melhor visualizados na Tabela 1, a seguir.

\section{Tabela 1 - Perfil sociodemográfico dos respondentes}

$\begin{array}{lcc}\text { Variáveis } & \text { Respondentes: } & \mathbf{1 6 5} \\ \text { Gênero } & \mathbf{N} & \mathbf{\%} \\ \text { Masculino } & 76 & 46,06 \% \\ \text { Feminino } & 73 & 44,24 \% \\ \text { Não Respondeu / Não Sabe } & 16 & 9,70 \% \\ \text { Faixa etária } & & \\ 15 \text { a } 19 & 30 & 18,18 \% \\ 20 \text { a } 24 & 30 & 18,18 \%\end{array}$

Revista Extensão \& Cidadania, v. 9, n. 16, p. 194-211, jul./dez. 2021. 


\begin{tabular}{|c|c|c|}
\hline 25 a 29 & 11 & $6,67 \%$ \\
\hline 30 a 34 & 11 & $6,67 \%$ \\
\hline 35 a 39 & 10 & $6,06 \%$ \\
\hline 40 a 44 & 7 & $4,24 \%$ \\
\hline 45 a 49 & 3 & $1,82 \%$ \\
\hline 50 a 54 & 2 & $1,21 \%$ \\
\hline 55 a 59 & 3 & $1,82 \%$ \\
\hline 60 a 64 & 2 & $1,21 \%$ \\
\hline \multicolumn{3}{|l|}{ Raça } \\
\hline Parda & 83 & $50,30 \%$ \\
\hline Preta & 46 & $27,88 \%$ \\
\hline Branca & 26 & $15,76 \%$ \\
\hline Indígena & 2 & $1,21 \%$ \\
\hline Amarela & 1 & $0,61 \%$ \\
\hline Não Declarado & 5 & $3,03 \%$ \\
\hline Não Respondeu / Não Sabe & 2 & $1,21 \%$ \\
\hline \multicolumn{3}{|l|}{ Escolaridade } \\
\hline Ensino Superior Completo & 47 & $28,48 \%$ \\
\hline Ensino Superior Incompleto & 48 & $29,09 \%$ \\
\hline Ensino Médio Completo & 45 & $27,27 \%$ \\
\hline Ensino Médio Incompleto & 13 & $7,88 \%$ \\
\hline Ensino Fundamental Completo & 5 & $3,03 \%$ \\
\hline Ensino Fundamental Incompleto & 5 & $3,03 \%$ \\
\hline Não Respondeu / Não Sabe & 2 & $1,21 \%$ \\
\hline \multicolumn{3}{|l|}{ Profissionalização } \\
\hline Empregado Formal & 60 & $36,36 \%$ \\
\hline Desempregado & 71 & $43,03 \%$ \\
\hline Empregado Informal & 23 & $13,94 \%$ \\
\hline Proprietário de Negócio & 10 & $6,06 \%$ \\
\hline Não Respondeu / Não Sabe & 1 & $0,61 \%$ \\
\hline
\end{tabular}

Fonte: Elaborado pelo autor.

Na Tabela 2, quando questionados se já estiveram presos, houve uma predominância de 90,91\% de que não, seguido de 7,88\% que não responderam e apenas $1,21 \%$ já estiveram presos(as).

Revista Extensão \& Cidadania, v. 9, n. 16, p. 194-211, jul./dez. 2021.

ISSN 2319-0566 DOI: 10.22481/recuesb.v9i16.8661 
Tabela 2 - Já esteve preso?

\begin{tabular}{lcr|}
\hline Já esteve preso & N & \% \\
\hline Sim & 2 & $1,21 \%$ \\
Não & 150 & $90,91 \%$ \\
Não informado & 13 & $7,88 \%$ \\
Total & 165 & $100 \%$ \\
\hline
\end{tabular}

Fonte: Elaborado pelo autor.

Depreende-se dos dados apresentados na Tabela 3, quando questionados sobre conhecer alguém que está ou que em algum momento esteve preso, 67,88\% responderam que conhecem alguém que está ou que já passou pelo sistema prisional, 24,24\% não conhece, seguido de 7,88\% que não sabe ou não respondeu à pergunta.

Tabela 3 - Conhece alguém que está ou já esteve preso?

\begin{tabular}{|lcc|}
\hline $\begin{array}{l}\text { Conhece alguém que está ou já esteve } \\
\text { preso? }\end{array}$ & N & \% \\
\hline Sim & 112 & $67,88 \%$ \\
Não & 40 & $24,24 \%$ \\
Não respondeu /Não sabe & 13 & $7,88 \%$ \\
Total & 165 & $100 \%$ \\
\hline
\end{tabular}

Fonte: Elaborado pelo autor.

Segundo as informações constantes na Tabela 4, 38,79\% da amostra não sabem ou não responderam à pergunta, seguido de 29,09\% correspondente a conhecidos distantes. Seguidos de $29,09 \%$ conhecidos distantes e $16,975 \%$ de pessoas próximas.

Tabela 4 - Qual sua proximidade com essa pessoa?

\begin{tabular}{lcc|}
\hline \multicolumn{1}{c}{ Variável } & N & \% \\
\hline Conhecido distante & 48 & $29,09 \%$ \\
Parente & 25 & $15,15 \%$ \\
Pessoa próxima & 28 & $16,97 \%$ \\
Não respondeu / Não sabe & 64 & $38,79 \%$ \\
Total & 165 & $100 \%$ \\
\hline
\end{tabular}

Fonte: Elaborado pelos autores.

Conforme a Tabela 5, na pergunta: Quem passa pelo sistema penitenciário brasileiro, mesmo após ter cumprido sua pena, muitas vezes fica marcado como ex-presidiário ou até

Revista Extensão \& Cidadania, v. 9, n. 16, p. 194-211, jul./dez. 2021.

ISSN 2319-0566 DOI: 10.22481/recuesb.v9i16.8661 
mesmo bandido, o que torna mais difícil conseguir um emprego. Se pudesse, você contrataria uma pessoa ex-presidiária? 38,16\% dos respondentes talvez contratassem um egresso do sistema penal, seguido de $28,29 \%$ que afirmaram não ter essa disposição, pois ficariam com receio dos(as) ex-presidiários(as) e 25,66\% dos respondentes disseram que sim, que com certeza, se pudessem, contratariam uma pessoa ex-presidiária.

\section{Tabela 5 - Você contrataria uma pessoa ex-presidiária?}

\begin{tabular}{lccc|}
\hline $\begin{array}{l}\text { Contrataria uma pessoa } \\
\text { presidiária? }\end{array}$ & ex- & N & \% \\
\hline Não & 12 & $7,89 \%$ \\
Talvez & 58 & $38,16 \%$ \\
Sim, mas ficaria com receio & 43 & $28,29 \%$ \\
Sim, com certeza & 39 & $25,66 \%$ \\
Total & 152 & $100 \%$ \\
\hline
\end{tabular}

Fonte: Elaborado pelo autor.

A sociedade, de um modo geral, passa a excluir pessoas privadas de liberdade ou que tenham passado algum momento da sua vida pelo sistema prisional. Muitos desses delinquentes encontraram enormes dificuldades em se inserir novamente na sociedade, pois aquele que comete um ato criminoso sempre será lido como ex-criminoso.

O trabalho é um dos instrumentos fundamentais para a reinserção social do ex-apenado, no entanto, o trabalho encontra-se para o ex-apenado diante de enormes barreiras criadas pela sociedade que se justifica pelo medo, receio, e o preconceito enraizado (LEANDRO, CÓDOVA; CASTRO; KERN, 2018). Os 38,16\% e os 28,29\% que representam a maioria dos respondentes que talvez ou sim, mas ficaria com receio de contratar um egresso do sistema penal mais adiante na Tabela 7 criam estratégias discursivas no sentido de estarem protegendo a si mesmo e aos outros do o "grau de periculosidade dessa pessoa".

$\mathrm{Na}$ Tabela 6, os dados analisados evidenciam que quando questionados se teriam algum receio em trabalhar com um ex-presidiário, 70,91\% da amostra disseram que não, seguidos de $15,15 \%$ da amostra que sim, teriam receio de trabalhar com essa pessoa.

Revista Extensão \& Cidadania, v. 9, n. 16, p. 194-211, jul./dez. 2021. 
Tabela 6 - Você teria algum receio de trabalhar com essa pessoa?

\begin{tabular}{lcc|}
\hline $\begin{array}{l}\text { Teria algum receio de trabalhar com } \\
\text { essa pessoa }\end{array}$ & $\mathbf{N}$ & $\boldsymbol{\%}$ \\
\hline Sim & 25 & $15,15 \%$ \\
Não & 117 & $70,91 \%$ \\
Não respondeu / Não sabe & 23 & $13,94 \%$ \\
Total & 165 & $100 \%$ \\
\hline
\end{tabular}

Fonte: Elaborado pelo autor.

Quando os respondentes afirmam que não, não teriam medo de trabalhar com indivíduo que, por uma série de fatores dos mais distintos, ingressou no caminho do crime, há uma contradição nas suas afirmações, como na Tabela 5 a maioria das resposta foi que talvez ou que sim, mas ficaria com receio de contratar uma pessoa ex-presidiária e na Tabela 7 afirmar que o medo, a falta de confiança ou por uma questão de segurança, podemos perceber que esse caminho de reintegrar ou de fazer com que o indivíduo retorne à sociedade ainda não se apresenta consolidado por parte da sociedade "livre".

$\mathrm{Na}$ Tabela 7, optou-se em extrair as principais falas dos sujeitos que quando questionados quais seriam os receios de trabalharem com os indivíduos privados de liberdade as respostas mais representativas foram:

Tabela 7 - Qual receio teria em trabalhar com essa pessoa?

\begin{tabular}{|l|l|}
\hline Respondente 2 & Medo da pessoa voltar a fazer algum crime. \\
\hline Respondente 26 & Não confiaria nela. \\
\hline Respondente 107 & O dela está mentindo sobre suas intenções. \\
\hline Respondente 115 & Não sei o grau de periculosidade dessa pessoa. \\
\hline Respondente 121 & $\begin{array}{l}\text { Teria que conversar, saber o perfil e avaliar seu histórico de } \\
\text { comportamento. }\end{array}$ \\
\hline
\end{tabular}

Fonte: Elaborado pelo autor.

Denota-se que os estigmas imputados, ao longo dos anos àqueles que em algum momento transgrediram a lei, marcarão para sempre esses indivíduos, como apontado por Cabral (2014, p. 48) "É a partir dessa mudança de identidade (de preso para ex-preso) que há a inclusão do rótulo aos indivíduos, conferindo-lhes uma identidade social negativa que fragiliza e dificulta os vínculos sociais." Ou seja, basta um desvio da conduta imposta pela sociedade para que esses indivíduos percam ou sejam retiradas suas identidades individuais "boas" e passem a receber uma nova identidade negativa que é socialmente construída.

Revista Extensão \& Cidadania, v. 9, n. 16, p. 194-211, jul./dez. 2021. 
Segundo as informações constantes na Tabela 8, podemos verificar que, ao considerar os motivos que levam os indivíduos às práticas delituosas, observou-se que os problemas estruturais, tais como político, econômico, cultural, social e dentre outros, representam 41,92\% dos motivos atinentes às práticas delituosas, seguido de $22,73 \%$ de problemas individuais, como transtornos mentais, biológicos e de caráter ético.

A Tabela 8 está baseada no modelo elaborado por Cerqueira e Lobão (2004, p. 255) que asseveram "[...] o número de crimes da localidade é determinado pelas variáveis: desigualdade de renda; renda esperada no mercado de trabalho legal (que depende da taxa de ocupação); densidade demográfica; poder de polícia; e valor da punição”, ou seja, a principal motivação para práticas delituosas é variável a depender da localidade, mas tem como principal motivação os fatores econômicos. Embora, ao considerar esses fatores econômicos como principal motivação, eles não são suficientes para justificar a completude das práticas criminosas.

Tabela 8 - Na sua opinião, qual o motivo principal que leva as pessoas a cometerem crimes?

\begin{tabular}{lcc|}
\hline \multicolumn{1}{c}{ Motivo } & N & \% \\
\hline Estrutural & 83 & $41,92 \%$ \\
Institucional & 16 & $8,08 \%$ \\
Interpessoal & 19 & $9,60 \%$ \\
Individual & 45 & $22,73 \%$ \\
Não respondeu / Não sabe & 35 & $17,68 \%$ \\
Total & 198 & $100 \%$ \\
\hline
\end{tabular}

Fonte: Elaborado pelo autor.

\section{Considerações finais}

Nesta pesquisa, buscou-se analisar a receptibilidade da sociedade "livre" as mensagens escritas por presos(as) no âmbito do projeto de extensão Narrativas dos Invisíveis mediante a coleta de dados e o amparo na literatura. Fazendo assim uma análise de uma possível reintegração social do(a) preso(a). Embora se reconheça que os dados obtidos na pesquisa não refletem a totalidade dos problemas enfrentados por pessoas presas numa possível reintegração social, observou-se que, de acordo com os resultados obtidos neste estudo que muitos dos

Revista Extensão \& Cidadania, v. 9, n. 16, p. 194-211, jul./dez. 2021. 
respondentes ainda reproduzem e produzem estereótipos e estigmas que colocam esses indivíduos como incorrigíveis.

Como podemos constatar na Tabela 5, quando questionados se após o cumprimento da pena você empregaria um ex-presidiário e na Tabela 7, quando questionados qual receio teria em trabalhar com essa pessoa, ficou explícito que um dos motivos impeditivos para uma possível reintegração da pessoa presa é a falta de oportunidades no mercado de trabalho. O trabalho é uma peça fundamental no processo de reintegração do indivíduo delinquente, pois por meio dele, o indivíduo garante os recursos necessários para sua sobrevivência e também para seus dependentes. Além das vantagens obtidas através do trabalho, o indivíduo se vê integrante e participativo na sociedade.

Assim, vê-se que indivíduos delinquentes encontram enormes dificuldades para se reintegrarem novamente na sociedade, pois esse processo não só envolve o apenado ou exapenado, mas também a construção de relações interpessoais que apenas se tornam possíveis com a quebra desses paradigmas socialmente construídos do delinquente. Dessa forma, se faz necessário cultivar esforços no sentido de promover essas mensagens escritas, com intuito de desconstruir o imaginário social sobre o sujeito preso. E também que haja investimento na educação e um ensino que envolva todas as pessoas da sociedade. Sem acabar com esses estereótipos e a falta de oportunidades no mercado de trabalho para estes indivíduos, não obteremos mudanças efetivas na ressocialização do apenado.

\section{Agradecimentos}

A presente pesquisa foi financiada através do Edital $n^{\circ}$ 04/2020, da Pró-Reitoria de Sustentabilidade e Integração Social, por meio da concessão de 01 (uma) Bolsa de Apoio à Permanência (BAP).

\section{Referências}

ASSIS, Rafael Damaceno de. A realidade atual do sistema penitenciário brasileiro. Revista CEJ, v. 11, n. 39, p. 74-78, out./dez. 2007.

Revista Extensão \& Cidadania, v. 9, n. 16, p. 194-211, jul./dez. 2021. 
BAHIA. Secretaria de Administração Penitenciária e Ressocialização (SEAP). Mapa da População Carcerária. Salvador, 2020. Disponível em: http://www.seap.ba.gov.br/ptbr/dados/17. Acesso em: 2 out. 2020.

BARATTA, Alessandro. Resocialización o control social: por un concepto crítico de "reintegración social" del condenado. Conferência apresentada no seminário criminología crítica y sistema penal, organizado pela Comisión Andina Juristas e pela Comisión Episcopal de Acción Social. Lima, de 17 a 21 de setembro de 1990. Tradução para o espanhol de Mauricio Martínez. Disponível em: http://perso.unifr.ch/derechopenal/assets/files/articulos/a_20120608_01.pdf. Acesso em: 30 set. 2020.

BARDIN, Laurence. Análise de conteúdo. Lisboa: Edições 70, 1988.

BRASIL, Luciana Leão. Michel Pêcheux e a teoria da análise de discurso: desdobramentos importantes para a compreensão de uma tipologia discursiva. Linguagem: estudos e pesquisas, v. 15, n. 1, p. 171-182, jan./jun. 2011. Disponível em: https://www.revistas.ufg.br/lep/article/view/32465/17293. Acesso em: 16 set. 2020.

BRASIL. Lei de Execução Penal (LEP). Lei no 7210 de 11 de julho de 1984. Institui a Lei de Execução Penal. Disponível em: https://www.planalto.gov.br/ccivil_03/leis/17210.htm. Acesso em: 16 set. 2020.

BRASIL. Levantamento Nacional de Informações Penitenciárias (INFOPEN). Atualização - junho de 2020. 2020. Disponível em: https://www.gov.br/depen/pt-br/sisdepen. Acesso em: 24 set. 2020.

CABRAL, Ruth do Prado. Reintegração social em Goiás: o perfil do apenado e a atuação do patronato em prol do egresso. 2014. 109 f. Dissertação (Mestrado em Direitos Humanos) Universidade Federal de Goiás, Goiânia, 2014.

CERQUEIRA, Daniel; LOBÃO, Waldir. Determinantes da criminalidade: arcabouços teóricos e resultados empíricos. Dados, v. 47, n. 2, p. 233-269, 2004.

DIAS, Cristiane Pereira. Da corpografia: ensaio sobre a língua/escrita na materialidade digital. Santa Maria: Ed. da UFSM, 2008.

FLAUZINA, Ana; PIRES, Thula. Cartas do cárcere: horizontes de resistência política. Revista Direito e Práxis, [S.1.], v. 10, n. 3, p. 2117-2136, set. 2019. Disponível em: https://www.e-publicacoes.uerj.br/index.php/revistaceaju/article/view/43885. Acesso em: 22 mar. 2021.

IBGE. Instituto Brasileiro de Geografia e Estatística. Censo demográfico. Brasil. Bahia. Teixeira de Freitas. 2010. Disponível em: https://cidades.ibge.gov.br/brasil/ba/teixeira-defreitas/panorama. Acesso em: 24 set. 2020.

Revista Extensão \& Cidadania, v. 9, n. 16, p. 194-211, jul./dez. 2021. 
LEANDRO, Maiara; CÓRDOVA, Zolnei Vargas de; CASTRO, Amanda; KERN, Cristina Adriana Rodrigues. Retorno à sociedade: percepções e experiências de ex-detentas. Revista de Psicologia da IMED, v. 10, n. 1, p. 125-139, jan./jun. 2018. Disponível em:

https://dialnet.unirioja.es/servlet/articulo?codigo=6548882. Acesso em: 5 out. 2020 .

ONOFRE, Elenice Maria Cammarosano. A leitura e a escrita como possibilidade de resgate da cidadania de jovens e adultos em privação de liberdade. Revista Educação e Linguagens, Campo Mourão, v. 1, n. 1, ago./dez. 2014. Disponível em:

http://www.fecilcam.br/revista/index.php/educacaoelinguagens/article/view/609. Acesso em: 5 out. 2020.

PIRES, Thula; FREITAS, Felipe (org.). Vozes do cárcere: ecos da resistência política. Rio de Janeiro: Kitabu, 2018.

RIBEIRO, José Roberto Ferreira; BRITO, Rafael Giordano Gonçalves; OLIVEIRA, Tarsis Barreto. A ressocialização do apenado por meio da participação da sociedade: o trabalho como instrumento no processo de reintegração, Vertentes do Direito, v. 5, n. 1, p. 190-212, 2018. Disponível em:

https://sistemas.uft.edu.br/periodicos/index.php/direito/article/view/5004/13255. Acesso em: 10 set. 2020.

SILVA, Roberto da. Didática no cárcere II: entender a natureza para entender o ser humano e o seu mundo. São Paulo: Giostri, 2018.

SILVA, Vera Lucia da. Sujeitos segregados: a língua e a história na produção epistolar de presidiários. 2014. 209 f. Tese (Doutorado em Linguística) - Universidade Estadual de Campinas, Instituto de Estudos da Linguagem, Campinas, 2014.

WORLD PRISON BRIEF. World Prison Population List. 11th ed., London: University of London; Institute for Criminal Policy Research, 2018. Disponível em:

https://www.prisonstudies.org/highest-to-lowest/prison-populationtotal?field_region_taxonomy_tid=All. Acesso em: 2 out. 2020.

Recebido: 14.05.2021

Aceito: 29.09 .2021

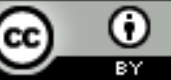

This work is licensed under a Creative Commons Attribution 4.0 International License.

(c) (i)

nternacional.

Este trabalho está licenciado com uma Licença Creative Commons - Atribuição 4.0

Revista Extensão \& Cidadania, v. 9, n. 16, p. 194-211, jul./dez. 2021. 